\title{
Calcification of vestibular schwannoma: a case report and literature review
}

\author{
Yang Zhang ${ }^{1}$, Jinlu Yu', Limei $\mathrm{Qu}^{2}$ and Yunqian $\mathrm{Li}^{{ }^{*}}$
}

\begin{abstract}
Calcification rarely occurs in vestibular schwannoma (VS), and only seven cases of calcified VS have been reported in the literature. Here, we report a 48-year-old man with VS, who had a history of progressive left-sided hearing loss for 3 years. Neurological examination revealed that he had left-sided hearing loss and left cerebellar ataxia. Magnetic resonance imaging and computerized tomography angiography showed a mass with calcification in the left cerebellopontine angle (CPA). The tumor was successfully removed via suboccipital craniotomy, and postoperative histopathology showed that the tumor was a schwannoma. We reviewed seven cases of calcified VS that were previously reported in the literature, and we analyzed and summarized the characteristics of these tumors, including the calcification, texture, and blood supply. We conclude that calcification in VS is associated with its texture and blood supply, and these characteristics affect the surgical removal of the tumor.
\end{abstract}

Keywords: Vestibular schwannoma, Calcification, Cerebellopontine angle, Surgery

\section{Background}

Vestibular schwannoma (VS), often called acoustic neuroma, is a common cerebellopontine angle (CPA) tumor. Calcification rarely occurs in vestibular schwannoma, and only seven cases of calcified VS have been reported in the literature [1-6]. Calcification of VS causes difficulties in the differential diagnosis of CPA tumors mainly because calcifications have been found in other CPA tumors, such as meningiomas, cavernous angiomas, gangliogliomas, and solitary fibrous tumors [7-10]. Calcified VS is often misdiagnosed before surgery largely due to insufficient numbers of reported cases and the lack of a comprehensive literature review on this type of tumor. In addition, calcification produces a change in the texture of VS, which can lead to difficulties in surgically removing the tumor [11]. Here, we report a case of calcified VS and summarize a literature review of seven cases of calcified VS. Our aim was to identify the relationship between calcified VS and the texture and blood supply of the tumor in order to guide the surgical treatment of calcified VS.

\footnotetext{
* Correspondence: yunqianli@gmail.com

${ }^{1}$ Department of Neurosurgery, First Hospital of Jilin University, 71 Xinmin Avenue, Changchun 130021, China

Full list of author information is available at the end of the article
}

\section{Case presentation}

The patient, a 48-year old man, was hospitalized for progressive left-sided hearing loss for 3 years. Upon examination, he had left-sided hearing loss. He also had an abnormal finger-nose pointing test, an abnormal rapid alternating movement, and a heel-knee-shin ataxia on the left side. He did not present with facial palsy and had normal muscle tone in the extremities. Magnetic resonance imaging (MRI) of the brain showed a round mass with a size of $5.42 \times 4.27 \times 5.35 \mathrm{~cm}$ in the left CPA region. The lesion was hypointense in the T1-weighted imaging (T1WI) and unevenly hyperintense in the T2weighted imaging (T2WI). Heterogeneous enhancement in the tumor was observed in the contrast-enhanced MRI. The left cerebellum, the fourth ventricle, and the brain stem were compressed (Figure 1). Computerized tomography angiography (CTA) of the head revealed a high-density, patchy calcification shadow on the left CPA region. The lesion had a clear boundary with the intracranial vessels, and no intracranial artery malformation was observed. The tumor was not stained on the CTA image (Figure 2). Based on the clinical symptoms and signs, as well as the MRI and CTA findings, the patient was diagnosed with calcified VS.

The patient underwent a left retrosigmoid suboccipital craniotomy and total excision of the tumor with
Ciomed Central

(c) 2012 Zhang et al.; licensee BioMed Central Ltd. This is an Open Access article distributed under the terms of the Creative Commons Attribution License (http://creativecommons.org/licenses/by/2.0), which permits unrestricted use, distribution, and reproduction in any medium, provided the original work is properly cited. 


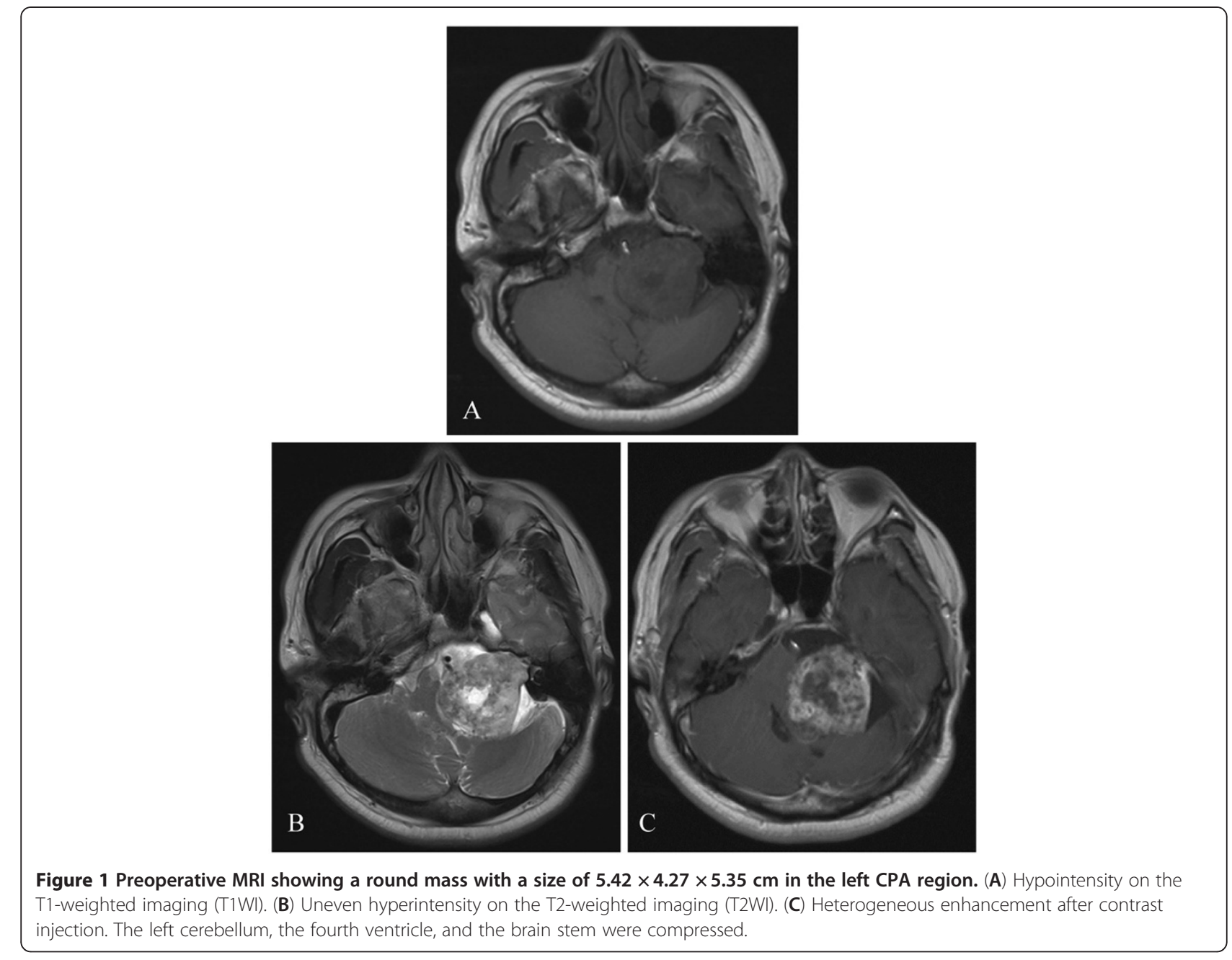

preservation of the facial nerve. The tumor, with a complete capsule originating from the internal auditory canal, was highly vascularized. It was yellow-grayish in color, and soft and brittle in texture. The tumor was cystic in the center and calcified in the periphery. After surgery, the patient had mild facial palsy and no improvement in left-sided hearing. At 1 week post surgery, the patient underwent a computerized tomography $(\mathrm{CT})$
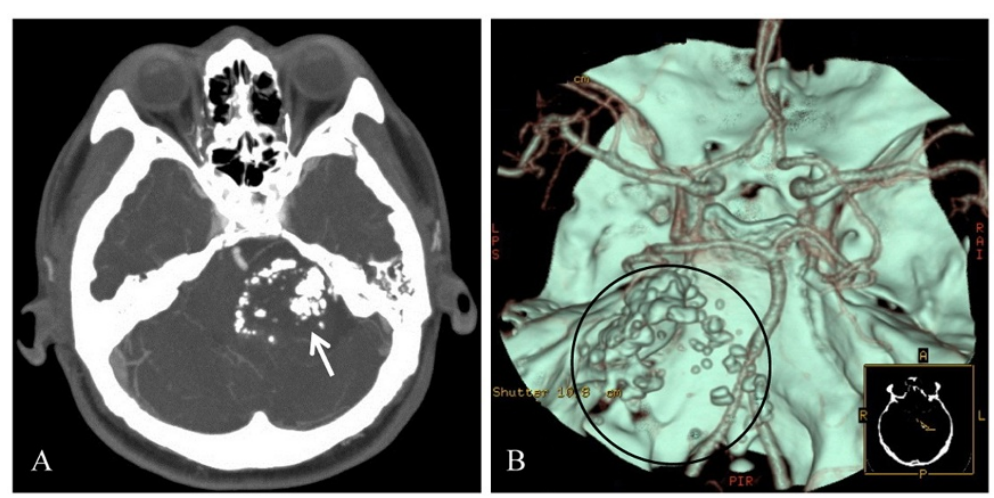

Figure 2 Preoperative CTA images showing calcification and the intracranial artery. (A) A high-density, patchy calcification shadow on the left CPA region (arrow). (B) The tumor (indicated by the circle) has a clear boundary with intracranial vessels. No intracranial artery malformation is observed. The tumor is not stained. 
scan and MRI, which showed that the tumor was completely removed (Figure 3). The histopathology of the tumor was suggestive of schwannoma. Hematoxylin and eosin (H \& E) staining showed strongly stained nuclei and interstitial hyaline degeneration. In addition, a large patchy calcification was observed (Figure 4). The patient had complete loss of left-sided hearing and an improvement in the facial palsy at the 6-month postoperative follow-up appointment.

\section{Literature review}

We performed a Medline literature search to identify cases of calcified VS that had been reported between 1980 and 2011. We found seven cases of calcified VS in six papers. Table 1 shows the summary of the seven cases of calcified VS.

The seven cases included five men and two women with a mean disease duration of 9.6 years (range, $0.5-$ to 30 years). All of these patients presented with the initial symptom of hearing loss, and two patients also presented with facial numbness. Neurological examinations were performed in six patients, and CPA symptoms with different severities were identified in these patients.

All the patients underwent $\mathrm{CT}$ scanning, and calcification in the VS was clearly observed on the CT scans. A conglomerate of dense calcifications in the VS was reported in three cases, and local calcified deposits were reported in four cases. MRI was performed in five of seven cases. Hypointensity on T1WI and hyperintensity on T2WI were found in four cases, and heterogeneous signals on both T1WI and T2WI were observed in one case. Contrast-enhanced MRI was performed in four of five cases. Heterogeneous enhancement was identified in three cases, and homogeneous enhancement was found in one case. Digital subtraction angiography (DSA) was performed in two cases, in which no tumors were stained in the images.

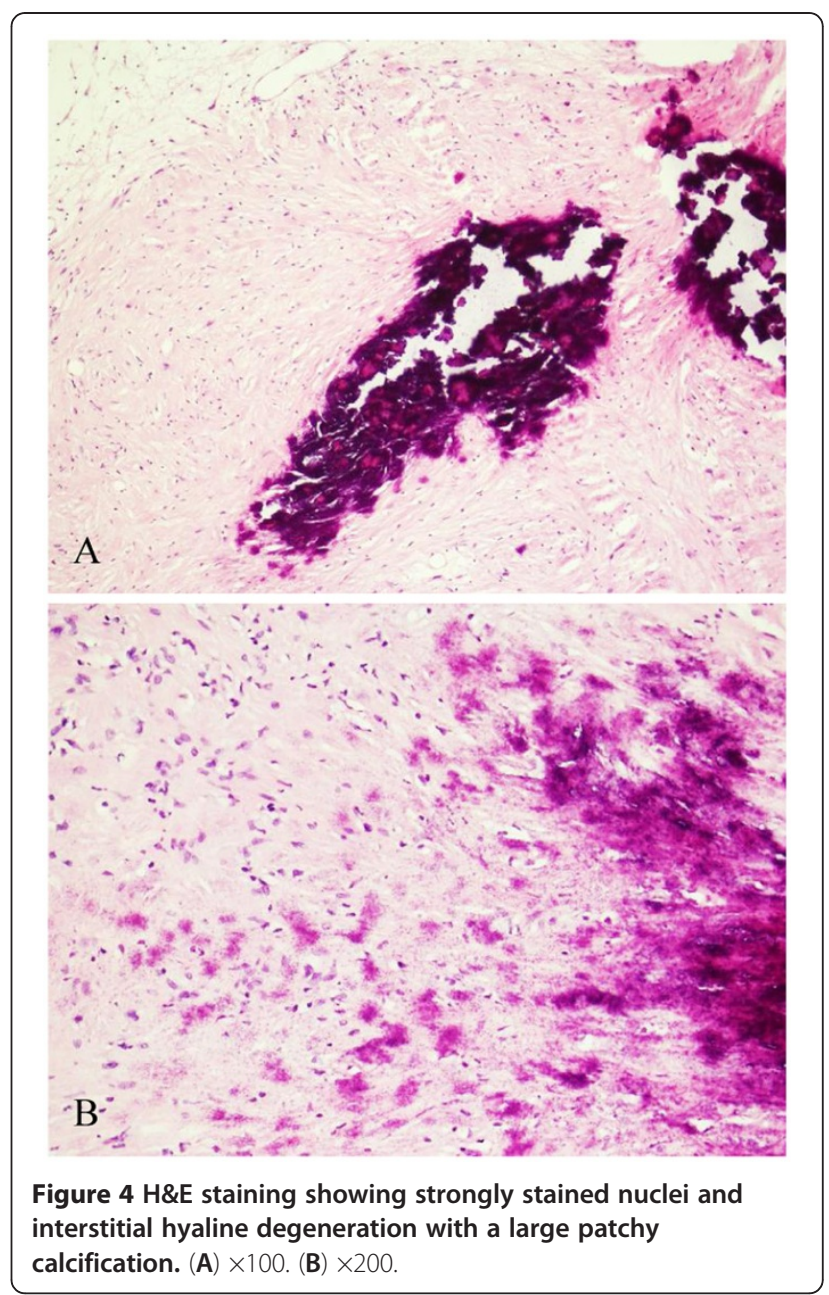

The tumor was removed via the translabyrinthine approach in two cases and via the suboccipital approach in five cases. Total excision of the tumor was performed in five cases, and subtotal excision was performed in two cases. The detailed surgical procedure was described for four cases, in which the tumor was hard in three cases
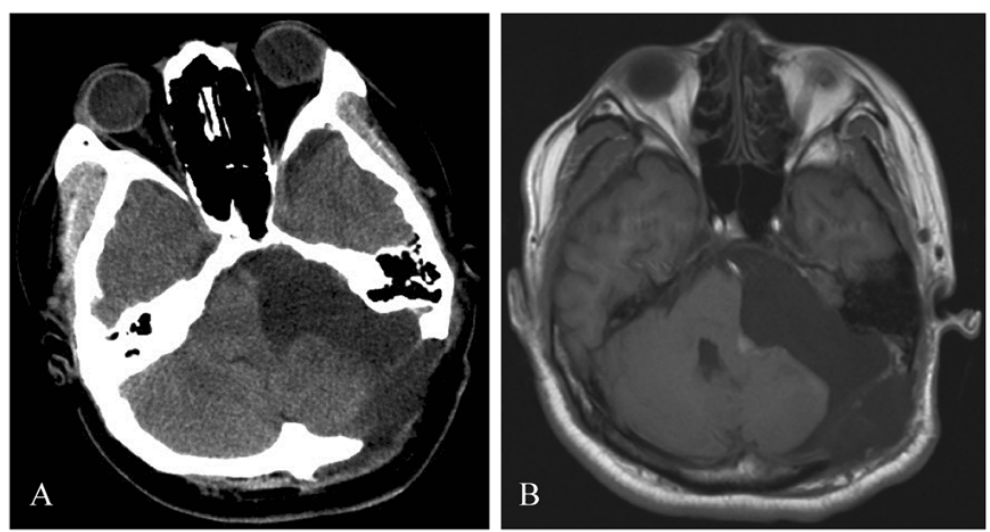

Figure 3 Postoperative CT (A) and MRI (B) showing complete removal of the tumor. 
Table 1 Summary of calcified VS cases

\begin{tabular}{|c|c|c|c|c|c|c|c|}
\hline Case & Author/year & Age/sex & $\begin{array}{l}\text { Duration of } \\
\text { disease }\end{array}$ & $\begin{array}{l}\text { Symptoms and } \\
\text { signs }\end{array}$ & Radiological findings & Surgical findings & $\begin{array}{l}\text { Postoperative } \\
\text { complications }\end{array}$ \\
\hline \multirow[t]{2}{*}{1} & $\begin{array}{l}\text { Thomsen/1984 } \\
\text { [1] }\end{array}$ & 44/male & 2 years & $\begin{array}{l}\text { Progressive right- } \\
\text { sided hearing loss } \\
\text { with a unilateral } \\
\text { sensorineural } \\
\text { hearing } \\
\text { impairment }\end{array}$ & $\begin{array}{l}\text { CT: a mass with a size of } 2 \\
\times 3 \mathrm{~cm} \text { with a } \\
\text { conglomerate of dense } \\
\text { calcification in the right } \\
\mathrm{CPA} \text {, moderate } \\
\text { enhancement after } \\
\text { contrast injection, normal } \\
\text { internal auditory canal }\end{array}$ & $\begin{array}{l}\text { Approach: } \\
\text { translabyrinthine } \\
\text { craniotomy twice, subtotal } \\
\text { removal of the tumor at } \\
\text { the initial operation, and } \\
\text { total removal of the tumor } \\
\text { after } 5 \text { months }\end{array}$ & $\begin{array}{l}\text { DysdiadokinesisMild } \\
\text { facial palsy }\end{array}$ \\
\hline & & & & $\begin{array}{l}\text { Examination: } \\
\text { spontaneous } \\
\text { nystagmus, gait } \\
\text { disturbance, and a } \\
\text { positive Romberg } \\
\text { test }\end{array}$ & & $\begin{array}{l}\text { Tumor: whitish, hard, and } \\
\text { highly vascularized }\end{array}$ & \\
\hline \multirow[t]{2}{*}{2} & Beskin/1989 [2] & 47/male & 15 years & $\begin{array}{l}\text { Progressive left- } \\
\text { sided hearing loss } \\
\text { with ringing and } \\
\text { itching deep in } \\
\text { the left canal }\end{array}$ & $\begin{array}{l}\text { MRI: Hypointensity on } \\
\text { T1WI and hyperintensity } \\
\text { on T2WI }\end{array}$ & $\begin{array}{l}\text { Approach: left posterior } \\
\text { fossa craniotomy, total } \\
\text { removal of the tumor after } \\
\text { debulking }\end{array}$ & Mild facial palsy \\
\hline & & & & $\begin{array}{l}\text { Examination: no } \\
\text { response in } \\
\text { vestibular testing } \\
\text { in the left } \\
\text { labyrinth }\end{array}$ & $\begin{array}{l}\mathrm{CT} \text { : a } 3 \mathrm{~cm} \text { mass with } \\
\text { pronounced calcification in } \\
\text { the left } \mathrm{CPA} \text {, enhancement } \\
\text { after administration of } \\
\text { contrast medium, enlarged } \\
\text { internal auditory canal }\end{array}$ & $\begin{array}{l}\text { Tumor: rubbery } \\
\text { consistency }\end{array}$ & \\
\hline \multirow[t]{2}{*}{3} & Atlas/1992 [3] & 50/male & 2 years & $\begin{array}{l}\text { Progressive right- } \\
\text { sided hearing loss } \\
\text { with a unilateral } \\
\text { sensorineural } \\
\text { hearing } \\
\text { impairment }\end{array}$ & $\begin{array}{l}\mathrm{CT} \text { : a small mass in the } \\
\text { right enlarged internal } \\
\text { auditory canal with a } \\
\text { conglomerate of dense } \\
\text { calcification }\end{array}$ & $\begin{array}{l}\text { Approach: } \\
\text { translabyrinthine } \\
\text { craniotomy, total removal } \\
\text { of the tumor with } \\
\text { preservation of the facial } \\
\text { nerve }\end{array}$ & Complete palsy \\
\hline & & & & $\begin{array}{l}\text { Examination: not } \\
\text { described }\end{array}$ & & $\begin{array}{l}\text { Tumor: adhesion to the } \\
\text { facial nerve }\end{array}$ & \\
\hline \multirow[t]{3}{*}{4} & Tosaka/2002 [4] & $36 /$ male & 30 years & $\begin{array}{l}\text { Progressive left- } \\
\text { sided hearing loss }\end{array}$ & $\begin{array}{l}\text { MRI: a mass with a size of } \\
3.5 \times 3 \times 2.5 \mathrm{~cm} \text { in the } \\
\text { CPA, hypointensity on } \\
\text { T1WI and hyperintensity } \\
\text { on T2WI, heterogeneous } \\
\text { enhancement after } \\
\text { gadolinium administration }\end{array}$ & $\begin{array}{l}\text { Approach: left suboccipital } \\
\text { craniotomy, removal of } \\
90 \% \text { of the tumor }\end{array}$ & $\begin{array}{l}\text { Hearing was worse } \\
\text { on the left side after } \\
\text { surgery than before } \\
\text { surgery }\end{array}$ \\
\hline & & & & $\begin{array}{l}\text { Examination: left } \\
\text { hearing loss, left } \\
\text { canal paresis }\end{array}$ & $\begin{array}{l}\mathrm{CT} \text { : significant calcification } \\
\text { on the tumor that } \\
\text { protruded to the enlarged } \\
\text { internal auditory canal }\end{array}$ & $\begin{array}{l}\text { Tumor: whitish, elastic, } \\
\text { hard, fibrous, and } \\
\text { demarcated with a rich } \\
\text { blood supply }\end{array}$ & No facial palsy \\
\hline & & & & & DSA: no tumor stain & & \\
\hline \multirow[t]{3}{*}{5} & Katoh/2007 [5] & 59/female & 15 years & $\begin{array}{l}\text { A long history of } \\
\text { CPA tumor with } \\
\text { no treatment, } \\
\text { admitted to the } \\
\text { hospital following } \\
\text { an epileptic } \\
\text { seizure }\end{array}$ & $\begin{array}{l}\text { MRI: a mass with a } 3 \mathrm{~cm} \\
\text { diameter in the CPA, } \\
\text { heterogeneous intensity } \\
\text { on T1WI and T2WI, } \\
\text { heterogeneous } \\
\text { enhancement after } \\
\text { gadolinium administration }\end{array}$ & $\begin{array}{l}\text { Approach: left suboccipital } \\
\text { craniotomy, subtotal } \\
\text { removal of the tumor }\end{array}$ & No facial palsy \\
\hline & & & & $\begin{array}{l}\text { Examination: left } \\
\text { deafness, left } \\
\text { nystagmus, and } \\
\text { left cerebellar } \\
\text { ataxia }\end{array}$ & $\begin{array}{l}\mathrm{CT} \text { : circular calcification in } \\
\text { the periphery of the tumor }\end{array}$ & $\begin{array}{l}\text { Tumor: yellow-grayish, } \\
\text { soft, with rich blood } \\
\text { supply and old hematoma } \\
\text { inside the tumor }\end{array}$ & \\
\hline & & & & & DSA: no tumor stain & & \\
\hline 6 & $\begin{array}{l}\text { Gopalakrishnan/ } \\
2011[6]\end{array}$ & 65/male & 3 years & $\begin{array}{l}\text { Progressive left- } \\
\text { sided hearing loss }\end{array}$ & $\begin{array}{l}\text { MRI: hypointensity on } \\
\text { T1WI, and heterogeneous } \\
\text { hyperintensity on T2WI, }\end{array}$ & $\begin{array}{l}\text { Approach: left suboccipital } \\
\text { craniotomy, total removal } \\
\text { of the tumor }\end{array}$ & \\
\hline
\end{tabular}


Table 1 Summary of calcified VS cases (Continued)

\begin{tabular}{|c|c|c|c|c|c|c|c|}
\hline & & & & $\begin{array}{l}\text { with facial } \\
\text { numbness }\end{array}$ & $\begin{array}{l}\text { heterogeneous } \\
\text { enhancement after } \\
\text { gadolinium administration }\end{array}$ & & \\
\hline & & & & $\begin{array}{l}\text { Examination: left } \\
\text { hypoesthesia and } \\
\text { facial palsy, and } \\
\text { sensorineural } \\
\text { hearing loss }\end{array}$ & $\begin{array}{l}\mathrm{CT} \text { : a mass with a } 3 \mathrm{~cm} \\
\text { diameter in the left CPA } \\
\text { with a conglomerate of } \\
\text { dense calcification, and } \\
\text { enlarged internal auditory } \\
\text { canal }\end{array}$ & Tumor: not described & $\begin{array}{l}\text { Death due to } \\
\text { myocardial } \\
\text { infarction }\end{array}$ \\
\hline \multirow[t]{2}{*}{7} & $\begin{array}{l}\text { Gopalakrishnan/ } \\
2011 \text { [6] }\end{array}$ & 31/female & 6 months & $\begin{array}{l}\text { Right-sided } \\
\text { deafness with } \\
\text { facial numbness }\end{array}$ & $\begin{array}{l}\text { MRI: hypointensity on } \\
\text { T1WI, and heterogeneous } \\
\text { hyperintensity on } \mathrm{T} 2 \mathrm{WI} \\
\text { homogenous } \\
\text { enhancement after } \\
\text { gadolinium administration }\end{array}$ & $\begin{array}{l}\text { Approach: left suboccipital } \\
\text { craniotomy, total removal } \\
\text { of the tumor }\end{array}$ & \\
\hline & & & & $\begin{array}{l}\text { Examination: } \\
\text { hypoesthesia on } \\
\text { the right side of } \\
\text { the face, and right } \\
\text { sensorineural } \\
\text { hearing loss }\end{array}$ & $\begin{array}{l}\mathrm{CT} \text { : a mass with a } 5 \mathrm{~cm} \\
\text { diameter in the left CPA } \\
\text { with two local deposits of } \\
\text { calcification at the } \\
\text { periphery of the tumor, } \\
\text { and enlarged internal } \\
\text { auditory canal }\end{array}$ & Tumor: not described & $\begin{array}{l}\text { Facial palsy (with } \\
\text { unknown severity) }\end{array}$ \\
\hline \multirow[t]{2}{*}{8} & Present case & 48/male & 3 years & $\begin{array}{l}\text { Progressive left- } \\
\text { sided hearing loss }\end{array}$ & $\begin{array}{l}\text { MRI: a mass with a size of } \\
5.42 \times 4.27 \times 5.35 \mathrm{~cm} \text { in } \\
\text { the left CPA, hypointensity } \\
\text { on T1WI, hyperintensity on } \\
\text { T2Wl, and heterogeneous } \\
\text { enhancement in the } \\
\text { contrast-enhanced MRI }\end{array}$ & $\begin{array}{l}\text { Approach: left suboccipital } \\
\text { craniotomy, total removal } \\
\text { of the tumor with } \\
\text { preservation of the facial } \\
\text { nerve }\end{array}$ & $\begin{array}{l}\text { No improvement in } \\
\text { left hearing }\end{array}$ \\
\hline & & & & $\begin{array}{l}\text { Examination: left } \\
\text { hearing loss, left } \\
\text { cerebellar ataxia }\end{array}$ & $\begin{array}{l}\text { CTA: a high-density patchy } \\
\text { calcification on the left } \\
\text { CPA, no intracranial artery } \\
\text { malformation, and no } \\
\text { tumor stain }\end{array}$ & $\begin{array}{l}\text { Tumor: yellow-grayish in } \\
\text { color, soft and brittle in } \\
\text { texture with a rich blood } \\
\text { supply, and cysts found in } \\
\text { the center of the tumor }\end{array}$ & Mild facial palsy \\
\hline
\end{tabular}

and cystic and soft in one case. Tumors with a rich blood supply were reported in three cases.

Among the seven cases, two patients had no postoperative facial palsy, two patients had mild postoperative facial palsy, and one patient had complete facial palsy. The severity of postoperative facial palsy was not reported in one case. Postoperative death occurred in one case due to myocardial infarction complications.

\section{Discussion}

It is very rare for VS to demonstrate calcification. When calcification occurs, the schwannoma usually hardens, making it difficult to dissect the tumor surgically $[5,12,13]$. In addition, VS is located in the CPA at the base of the skull, which restricts surgical access to the tumor. The space constraints make the texture of the tumor an important factor that affects tumor dissection, as with craniopharyngioma in the sellar region [14]. However, it is unclear how calcification, texture, and the blood supply of the calcified VS affect surgical dissection of the tumor. In this study, we presented a case of calcified VS and reviewed the seven reported cases of calcified VS in the literature. We found that calcification in
VS is associated with the tumor's texture and blood supply, and these characteristics affect the surgical removal of the tumor.

The texture of the tumor is one of the factors that affect its surgical removal. The texture is dependent not only on calcification but also on cyst formation and hemorrhage inside the tumors $[15,16]$. We reviewed seven cases of calcified VS in the literature and found that four cases reported on the tumor texture. In three cases, the tumor was hard, and calcification was found in the VS; however, there was no cystic formation or hemorrhage. In one case, the tumor was soft, and an old hematoma was identified inside the tumor. These findings suggest that intratumoral cyst formation and hemorrhage can soften a calcified VS. Our case agrees with the hypothesis that cysts formed in calcified VS are soft in texture.

The tumor's blood supply is also a critical factor affecting surgical dissection of the tumor. Three of the seven cases in the literature reported a rich blood supply in the tumors and identified enhancement in contrastenhanced MRI or CT. However, no tumor staining was identified on angiography in two patients who 
underwent DSA. Consistent with these reports, no tumor staining was observed with CTA in our case, although a rich blood supply was identified during the operation. The finding that the tumor was not stained in the angiography is likely because the tumor was supplied by a thin artery that was difficult to stain using this procedure [17]. Total excision of the tumor was not performed in two of the seven cases, partly because of the rich blood supply. In our case, a total excision of the tumor was performed because of its softness.

The main surgeries for VS removal are translabyrinthine craniotomy and suboccipital craniotomy [18]. The seven calcified tumors were removed either via the translabyrinthine approach (in two cases) or via the suboccipital approach (in five cases). We used retrosigmoid suboccipital craniotomy to dissect the tumor, since this approach can extensively expose the CPA area and allows for the preservation and reconstruction of cranial nerves [19]. Facial paralysis is the major complication after surgical removal of VS. Postoperative facial palsy occurred in four of the seven cases of calcified VS reported in the literature. Two patients had mild postoperative facial palsy, and one patient had complete facial palsy. The severity of postoperative facial palsy was not reported in one case. In our case, the postoperative facial palsy was mild, and the patient recovered by the postoperative follow-up appointment at 6 months.

A calcified tumor in the CPA suggests a diagnosis of meningioma or cavernous angioma. Identification of the features of these tumors on MRI, CT, and angiography is critical for differential diagnosis among calcified VS, meningioma, and cavernous angioma. Meningiomas usually have a wide base attached to the dura mater and thus have characteristic dural tail signs on the MRI [20]. However, neither our case nor any of the calcified VS cases in the literature had the dural tail sign, suggesting that the dural tail sign may be used to differentiate meningiomas from calcified VS. In addition, meningiomas do not originate from the cranial nerve and, therefore, have different CPA symptoms from VS [21,22]. It is difficult to differentiate calcified VS from calcified cavernous angiomas that originate from the internal auditory canal, since they share some features on MRI (such as isointensity to hyperintensity on T1WI and hyperintensity on T2WI) [23].

\section{Conclusions}

In summary, we report a case of calcified VS and a literature review of seven cases of calcified VS. We analyzed the tumor's texture and blood supply, the radiological findings, and the surgical procedures. It is difficult to remove hard calcified VS with a rich blood supply. However, cystic formation in VS can soften the tumor, thus facilitating its dissection. We conclude that radiological findings are helpful to differentiate calcified VS from other tumors in the CPA.

\section{Consent}

Written informed consent was obtained from the patient for publication of this case report and the accompanying images. Copies of the written consent are available for review upon request.

\section{Competing interests}

The authors declare that they have no competing interests.

\section{Authors' contributions}

Yang Zhang and Yunqian Li wrote the initial draft. Jinlu Yu was the surgeon. Limei Qu performed the pathological examination. Yang Zhang and Jinlu Yu contributed equally to this work. All authors read and approved the final manuscript.

\section{Funding support}

This study had no funding support.

\section{Acknowledgements}

The authors thank Medjaden Bioscience for assisting in the preparation of this paper.

\section{Author details}

${ }^{1}$ Department of Neurosurgery, First Hospital of Jilin University, 71 Xinmin Avenue, Changchun 130021, China. ${ }^{2}$ Department of Pathology, First Hospital of Jilin University, 71 Xinmin Avenue, Changchun 130021, China.

Received: 18 April 2012 Accepted: 21 September 2012

Published: 2 October 2012

\section{References}

1. Thomsen J, Klinken L, Tos M: Calcified acoustic neurinoma. J Laryngol Otol 1984, 98:727-732.

2. Beskin RR, Eick JJ: Calcified acoustic neuroma. South Med J 1989, 82:1048-1050.

3. Atlas MD, Fagan PA, Turner J: Calcification of internal auditory canal tumors. Ann Otol Rhinol Laryngol 1992, 101:620-622.

4. Tosaka M, Hirato J, Miyagishima T, Saito N, Nakazato Y, Sasaki T: Calcified vestibular schwannoma with unusual histological characteristics positive immunoreactivity for CD-34 antigen. Acta Neurochir (Wien) 2002, 144:395-399.

5. Katoh M, Aida T, Imamura H, Aoki T, Yoshini M, Kashiwazaki D, Takei H: Calcified vestibular schwannoma in the cerebellopontine angle. J Clin Neurosci 2007, 14:1207-1209.

6. Gopalakrishnan CV, Shrivastava A, Nair S: Calcification in vestibular schwannoma: report of two cases and review of the literature. Neurol India 2011, 59:642-645.

7. Wu EH, Tang YS, Zhang YT, Bai RJ: CT in diagnosis of acoustic neuromas AJNR Am J Neuroradiol 1986, 7:645-650.

8. Sasaki T, Okamoto K, Ishida T, Kirino T: Cavernous angioma of the internal acoustic meatus-case report. Neurol Med Chir (Tokyo) 1999, 39:847-851.

9. Milligan BD, Giannini C, Link MJ: Ganglioglioma in the cerebellopontine angle in a child. Case report and review of the literature. J Neurosurg 2007, 107:292-296

10. Biggs ND, Fagan PA, Turner JJ, Doust B: Solitary fibrous tumor of the cerebello-pontine angle. Skull Base Surg 1999, 9:295-299.

11. Sabolch AN, Quint DJ, Zahuranec DB: Calcified brainstem cavernoma in a patient with hundreds of intracranial cavernomas. Neurologist 2010, 16:379-383

12. Hayashi F, Sakai T, Sairyo K, Hirohashi N, Higashino K, Katoh S, Yasui N: Intramedullary schwannoma with calcification of the epiconus. Spine J 2009, 9:e19-e23.

13. Moroni AL, Righini C, Faure C, Serra-Tosio G, Lefournier V: CT Features of an unusual calcified schwannoma of the superior laryngeal nerve. AJNR Am J Neuroradiol 2007, 28:981-982. 
14. Elliott RE, Moshel YA, Wisoff JH: Minimal residual calcification and recurrence after gross-total resection of craniopharyngioma in children. J Neurosurg Pediatr 2009, 3:276-283.

15. Lunardi P, Missori P, Mastronardi L, Fortuna A: Cystic acoustic schwannomas. Acta Neurochir (Wien) 1991, 110:120-123.

16. Park CK, Kim DC, Park SH, Kim JE, Paek SH, Kim DG, Jung HW: Microhemorrhage, a possible mechanism for cyst formation in vestibular schwannomas. J Neurosurg 2006, 105:576-580.

17. Li Y, Zhao G, Wang H, Zhu W, Qu L, Li Y, Yu J: Use of 3D-computed tomography angiography for planning the surgical removal of pineal region meningiomas using Poppen's approach: a report of ten cases and a literature review. World I Surg Oncol 2011, 9:64.

18. Arlt F, Trantakis C, Seifert V, Bootz F, Strauss G, Meixensberger J: Recurrence rate, time to progression and facial nerve function in microsurgery of vestibular schwannoma. Neurol Res 2011, 33:1032-1037.

19. Samii M, Gerganov VM, Samii A: Functional outcome after complete surgical removal of giant vestibular schwannomas. J Neurosurg 2010, 112:860-867.

20. Goldsmith B, McDermott MW: Meningioma. Neurosurg Clin N Am 2006, 17:111-120. vi.

21. Muller W, Firsching R: Considerations on the tendency for calcification in meningiomas. J Neurosurg Sci 1996, 40:83-87.

22. Kane AJ, Sughrue ME, Rutkowski MJ, Berger MS, McDermott MW, Parsa AT: Clinical and surgical considerations for cerebellopontine angle meningiomas. J Clin Neurosci 2011, 18:755-759.

23. Engh JA, Kostov D, St Martin MB, Yeaney G, Rothfus W, Hirsch B, Kassam AB: Cavernous malformation tumors: a case study and review of the literature. Otol Neurotol 2010, 31:294-298.

doi:10.1186/1477-7819-10-207

Cite this article as: Zhang et al:: Calcification of vestibular schwannoma: a case report and literature review. World Journal of Surgical Oncology 2012 10:207

\section{Submit your next manuscript to BioMed Central and take full advantage of:}

- Convenient online submission

- Thorough peer review

- No space constraints or color figure charges

- Immediate publication on acceptance

- Inclusion in PubMed, CAS, Scopus and Google Scholar

- Research which is freely available for redistribution 